\title{
An Evaluation Content In Curriculum 2013 At High School Stella Duce Dua Yogyakarta
}

\author{
Jemi Fantula ${ }^{1 *}$, Aman $^{2}$, Johan Setiawan ${ }^{3}$ \\ \{jemsong21@gmail.com ${ }^{1}$, aman.uny.ac.id ${ }^{2}$,johansetiawan767@gmail.com ${ }^{3}$ \} \\ ${ }^{1,2}$,Magister Pendidikan Sejarah, FIS, Universitas Negeri Yogyakarta \\ Alamat jln Colombo No 1, Karang Malang, Caturtunggal, Depok Seleman, DIY 55281 \\ ${ }^{3}$ Program Doktoral, Pascasarjana, Universitas Negeri Yogyakarta \\ ${ }^{3}$ Pendidikan Sejarah, Universitas Muhammadiyah Metro \\ Alamat jln Colombo No 1, Karang Malang, Caturtunggal, Depok Seleman, DIY 55281
}

\begin{abstract}
This study aims to reveal: (1) the effectiveness of implementing the curriculum in the aspects of goal, content, learning activities, and evaluation, and (2) curriculum discrepancy, this research is a program evaluation using a discrepancy evaluation with the quantitative approach. The program evaluation refers to the national standard criteria for education 2016. The instrument validation used the Aiken formula, and Microsoft Excel with the Pearson formula and reliability used Alpha Cronbach. Data analysis uses descriptive statistics. The results of the study show that (1) the average percentage of the efficient application of curriculum objectives is $82 \%$, curriculum content is $83 \%$, learning activities in the curriculum is $81 \%$, and curriculum evaluation is $88 \%$ curriculum evaluation; (2) the highest gap in the administration of the curriculum in High School Stella Duce Dua Yogyakarta is in the aspect of learning activities in the curriculum with the discrepancy of $19 \%$.
\end{abstract}

Keywords: curriculum evaluation, discrepancy evaluation

\section{Introduction}

The 2013 curriculum, in its implementation, experienced multiple challenges and obstacles. At the beginning of the performance of the 2013 curriculum, there are pros and cons. It is caused by the assumption that it does not appropriate with the expectations and the condition in the field. As one of the defining factors of the success of the 2013 curriculum, the teacher still feels confused with the implementation of the 2013 curriculum [1], [2]. 2013 curriculum evaluation development needs to be done through the accompaniment and supervision sustainably. As part of the curriculum development, curriculum evaluation is conducted at the beginning of the idea of curriculum development, document development, and implementation until the curriculum result already impacted the community [3]. Curriculum evaluation is a crucial component to assess how far and good the implementation and the learning process goes. Besides, curriculum evaluation can measure the effectiveness level of implementation in the school. With the evaluation, it can be seen whether the target can be achieved or not so that the feedback will be obtained and the weaknesses can be fixed [4]. 
There are several essential goals in curriculum evaluation: (1) knowing how far a student can achieve the progress which already determined, (2) assessing the curriculum effectiveness, (3) defining factors of cost, duration, and curriculum success level [5]. All of the aspects lead to the success of educational goals through the curriculum. At least, there are two factors on the 2013 curriculum success. The first one is determinant. It is the suitability between the competence of the teacher and educational staff and between curriculum component and textbook. The second one consists of three elements, (1) availability of books as teaching materials and learning sources that integrate the curriculum formation standards $[6]$.

Related to the importance of the teacher's role in the 2013 curriculum implementation, it aims to encourage the student to act better in observing, asking, thinking logically, and communicating what they got after through learning activity. On this side, the teacher plays a significant role in applying each learning process in the 2013 curriculum. The teacher's role as an implementer of the curriculum is affected by the support of academic staff to cultivate the curriculum implementation. Based on the description above, the researcher can identify the problem and obstacle that happen on the performance of the 2013 curriculum in SMA Stella Duce Dua Yogyakarta through the 2013 curriculum evaluation and follow-up the difficulties encountered in the implementation of the 2013 curriculum.

This evaluation is held to serve information about the good and the flawed process of the activity result. Evaluation is a systematic and continual process for gathering, describing, interpreting, and presenting information used as a basis for making decisions [7]. Safruddin and Arikunto said that evaluation is an activity to collect information about how things work, which later on the data used to decide the proper alternative way to take a decision [8]. Besides as an alternative way in making a decision, evaluation can interpret as an activity that is usually done for assessing the feasibility of a plan, implementation, and result of a program or policy [9]. Arifin said that evaluation is a systematic and sustainable process to define the quality (value and meaning) from the things based on the particular consideration and criteria to make a decision [10]. To make a decision, evaluation can be interpreted as a process to define the result achieved in several planned activities to achieve the goals. Based on Fitzpatrick, Sanders, and Worthen, evaluation is an activity to decide an object (valuable and acceptable) by identifying, clarifying, and amplifying the criteria [11]. All the requirements above are essential things. Evaluation is not only an activity to define the value, but Banner defines that evaluation as a learning program through collecting information. The information collected later on will be used as a base to make a decision [12]. As a base, evaluation has a procedure. Kossoff and Fink said that an evaluator uses a specific approach to assess service programs and provide information about the goals, expectations, activity, result, effect, and cost [13], [14], [15].

Malcolm Provus develops an evaluation model entitled Discrepancy Evaluation Model and use it in the research, which the subject of the curriculum. Generally, curriculum defines as an administration tool in the school to achieve the education goals. In a different meaning, the curriculum comes from Latin, cure, which means track, and culum, which means horse. Those points that curriculum is a track that a horse should pass while it is competing. The definition of the curriculum has various interpretations. As stated by Howell \& Nollet, "a curriculum is a structured set of learning outcomes, or tasks, that educator usually goals or objectives. The student is expected to learn the information specified in the curriculum to have the skills needed to transition from childhood into adult life. The curriculum is intended to prepare students to succeed in society" [16], [17]. 
The curriculum is seen as a set of curriculum education goals and has an important role. Therefore, the education goal will achieve. Curriculum-based on Seel \& Dijkstra defined that curriculum as a plan and instruction in a learning process (Sell \& Dijkstra, 2004). The learning plan will give the student needs a detailed explanation of how the learning process is held. "Curriculum development results in the construction of resource units, unit plans, courses, and other curriculum guides those teachers and students can utilize to help them learn more effectively." [18], [19]. The curriculum should be developed to simplify and facilitate the learning process [20].

The curriculum facilitates a learning process that needs to be explained in detail. Outline what students should learn in a specific school subject over the course of their study in a document published by an educational system. The curriculum makes all of the learning plans for students through the program caused by the education unit as a document that can bring students or lessons to achieve the education goals [20]. Based on Wright, Judith, \& Johnson, the education unit designed and planned the curriculum with load materials taught to students [21]. The curriculum is seen as an element covering students, teachers, and learning method that is used.

Elements that consist in a curriculum are a design provided by the school to achieve education goals. Omar Hamalik states that curriculum is an education program provided by the school institution [22]. Based on the education program, students do various learning activities to support the development and growth, which adjust with the education goals. In other words, a curriculum is a school program that provides an educational environment to growing up. That is why the curriculum is arranged so that students can do many kinds of learning activities [21], [23], [23], [24].

The curriculum is not limited to several subjects but also all the things that can affect the development of students, such as school building, learning tools, library, school staffs, paintings, schoolyard, and many more. Based on the explanation above, curriculum activities are not only in the classroom but also outdoors. The modern view explains that extracurricular and extracurricular activity has no clear division. From the several explanations above, it can be concluded that curriculum is all held by an educational institution that involves all the elementary education and involves all the documents and learning processes related to the learning method used.

\section{Research Methods}

This research is categorized as evaluative research by using the discrepancy evaluation model. The discrepancy evaluation done by curriculum program involves goals, content, process, and assessment towards learning result based on Permendikbud 2016 No 20, 21, 22, 23. The result of the curriculum program can be seen through the evaluation combatively. Later on, the result will be compared with the criteria program as a reference of fruitfulness. After measuring and achieving the implementation program, it can be concluded that as information, it becomes a program recommendation for the school. The kind of approach in this research is helped by using the quantitative method [25]. Assessment and program results showed numeric symbols such as average, percentage, and frequency distribution. All the quantitative data from the various measurement scale analyzed using statistic descriptive [26]. This research is done in the Stella Duce Dua Yogyakarta senior high school with evaluation subject of all XI students who are done the learning process by using the 2013 curriculum. Number of students in the XI class is 127 students. In detail, the amount of respondent based on their own classes are XI IPA=27, XI IPA 27, XI IPS $1=28$, XI IPS $2=28$, XI BB= 17 . 
Later on, collected data analyzed by using descriptive quantitative analysis. Questioner data analyzed quantitatively while interview data and documentation complete the questioner data. The analysis result of the curriculum will compare with the criteria that are already set. It can be seen through Table1.

Table 1. Criteria of Measurement Result

\begin{tabular}{ll}
\hline \multicolumn{1}{c}{ Score } & \multicolumn{1}{c}{ Result Category } \\
\hline $\mathrm{X} \geq \bar{x}+1 . \mathrm{S} . \mathrm{Bx}$ & Very Positive/Very High \\
$\bar{x}+1 . \mathrm{S} . \mathrm{Bx}>\mathrm{X} \geq \bar{x}$ & Positive/High \\
$\bar{x}>\mathrm{X} \geq \bar{x}-1 . \mathrm{S} . \mathrm{Bx}$ & Negative/Low \\
$\mathrm{X}<\mathrm{x}-1 . \mathrm{S} . \mathrm{Bx}$ & Very Negative/Very Low \\
\hline
\end{tabular}

\subsection{Curriculum Component Analysis}

Curriculum component analysis is done to know the category in every component already set in the school. Curriculum frequency distribution is based on the type of curriculum component [27]. It can be seen in Table 2 .

Table 2. Frequency Distribution of Curriculum Component

\begin{tabular}{|c|c|c|c|c|c|c|c|c|c|c|c|c|}
\hline \multirow{2}{*}{ No } & \multirow{2}{*}{$\begin{array}{l}\text { Range } \\
\text { of } \\
\text { Score }\end{array}$} & \multirow{2}{*}{ Category } & \multicolumn{2}{|c|}{ Objectives } & \multicolumn{2}{|c|}{ Content } & \multicolumn{2}{|c|}{$\begin{array}{c}\text { Learning } \\
\text { Activity }\end{array}$} & \multicolumn{2}{|c|}{ Evaluation } & \multicolumn{2}{|c|}{ Total } \\
\hline & & & $\mathrm{N}$ & $\%$ & $\mathrm{~N}$ & $\%$ & $\mathrm{~N}$ & $\%$ & $\mathrm{~N}$ & $\%$ & $\mathrm{~N}$ & $\%$ \\
\hline 1 & $\begin{array}{c}3,67- \\
5,00\end{array}$ & $\begin{array}{l}\text { Very } \\
\text { High }\end{array}$ & 104 & $82 \%$ & 110 & $87 \%$ & 100 & $79 \%$ & 119 & $94 \%$ & 108 & $85 \%$ \\
\hline 2 & $\begin{array}{l}3,00- \\
3,66\end{array}$ & High & 22 & $17 \%$ & 14 & $11 \%$ & 25 & $20 \%$ & 6 & $5 \%$ & 17 & $13 \%$ \\
\hline 3 & $\begin{array}{c}2,33- \\
2,99\end{array}$ & Low & 1 & $1 \%$ & 3 & $2 \%$ & 2 & $2 \%$ & 2 & $2 \%$ & 2 & $2 \%$ \\
\hline 4 & $\begin{array}{l}1,00- \\
2,33\end{array}$ & $\begin{array}{l}\text { Very } \\
\text { Low }\end{array}$ & 0 & $0 \%$ & 0 & $0 \%$ & 0 & $0 \%$ & 0 & $0 \%$ & 0 & $0 \%$ \\
\hline \multicolumn{3}{|c|}{ Total } & 127 & $100 \%$ & 127 & $100 \%$ & 127 & $100 \%$ & 127 & $100 \%$ & 127 & $100 \%$ \\
\hline
\end{tabular}

Table 2 shows the information on frequency distribution based on four curriculum components: goals, content, learning activity, and evaluation. Based on information in table 2, it can be seen that the category of frequency curriculum goals is $82 \%$ which very high, $17 \%$ high, $1 \%$ deficient, $0 \%$ deficient. The category of curriculum content frequency is $87 \%$, which is very high, $11 \%$ high, $2 \%$ low, and $0 \%$ deficient. Besides, the learning activity is $79 \%$ very high, $20 \%$ high, $2 \%$ low, $0 \%$ deficient. On curriculum evaluation is $94 \%$ very high, $5 \%$ high, $2 \%$ low, $0 \%$ very low. Information in Table 2 shows the 127 respondent's answers contain very high, high, low, very low.

The information in Table 2 shows the respondent's choice of answers in each category. Each category contains very high, high, low, and shallow criteria. One hundred twenty-seven respondents' responses can be seen in Figure 1. 


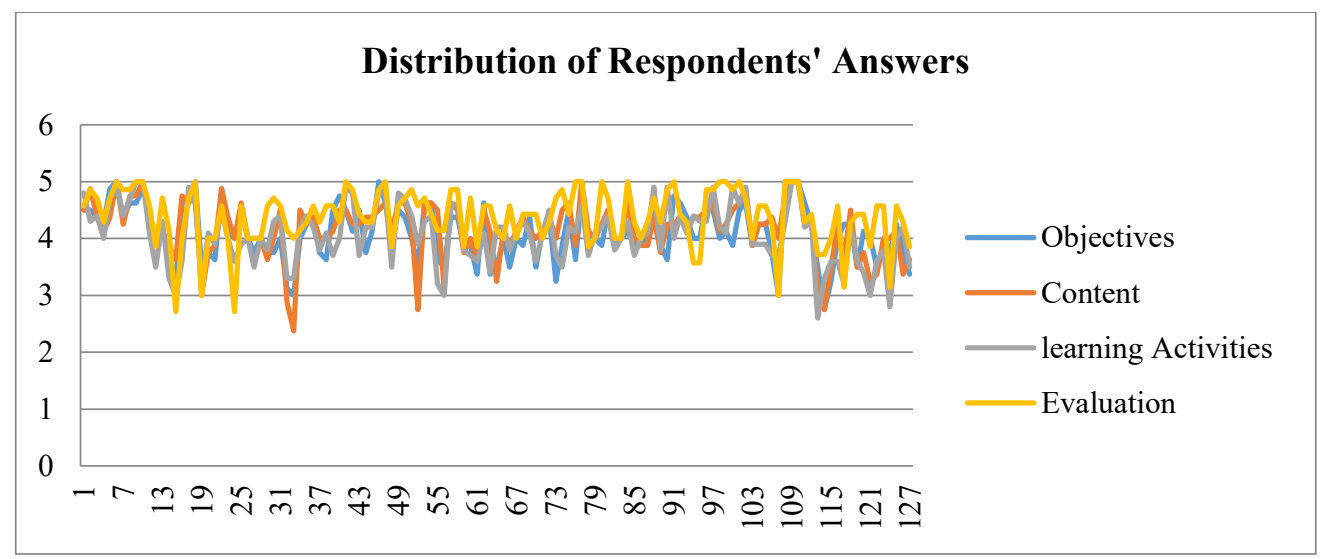

Figure 1. Distribution of Respondent's Answer

Figure 1 shows the average distribution of respondent's answers in choosing the score of curriculum component. The answer distribution not only gives information of four categories but also give information about the score distribution in each curriculum component, which is: range of score $3,67-5,00$ or $85 \%$ very high, range of score $3,00-3,66$ or $13 \%$ high, range of score $2,33-2,99$ or $2 \%$ low, and content of score $1,00-2,33$ or $0 \%$ deficient.

\subsection{Analysis of Component Goals}

Analysis of component goals of curriculum is a legal analysis of graduate competency [28]. Based on the analysis done on the curriculum goals component, the average result is 4,09 , which in the interval of 3,67-5,00. The result of component goals can be seen in Table 3 .

Table 3. Component Objectives of Curriculum

\begin{tabular}{ccccc}
\hline Component & Total score & Average & Percentage & Category \\
Objectives & 4165 & 4,09 & $82 \%$ & Very High \\
\hline
\end{tabular}

Based on the analysis result in table 3, the category is very high. The average is 4,09 . Therefore, an objective component of the curriculum is in the very high class. The result can be seen in Figure 2.

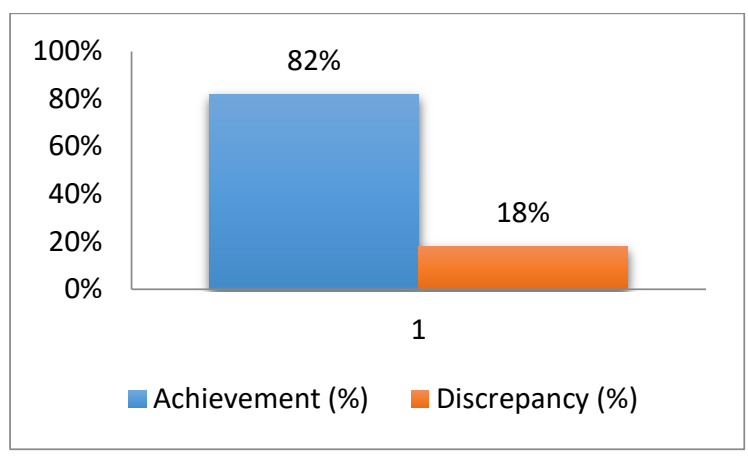

Figure 2. Achievement of an Objective Component of Curriculum 
Figure 2 displays achievement and curriculum discrepancy in the objective components. The research results explain that graduate competition has an average of 4,09 with $82 \%$ achievement and a difference of $18 \%$ so that graduate competency has a very high category.

\subsection{Content Component Analysis}

Content component analysis of curriculum is a formal content analysis[29], [30]. Analysis result on the curriculum content got an average of 4,16 \% in the 3,67-5,00 interval. The calculation of the content component of the curriculum can be seen in Table 4 .

Table 4. Content Component of Curriculum

\begin{tabular}{ccccc}
\hline Component & $\begin{array}{l}\text { Total } \\
\text { score }\end{array}$ & Average & Percentage & Category \\
\hline Content & 4231 & 4,16 & $82 \%$ & $\begin{array}{l}\text { Very } \\
\text { High }\end{array}$ \\
\hline
\end{tabular}

Based on the result analysis in Table4, the component content of the curriculum has a very high category. The average is 4,16 . The content component $f$ the curriculum can be seen clearly in Figure 3.

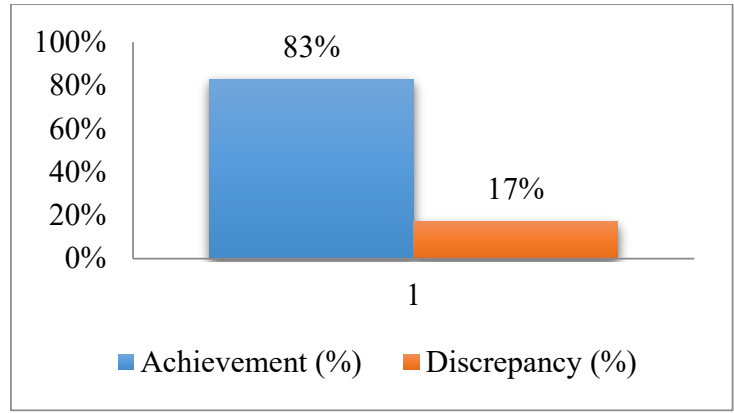

Figure 3. Component Content of Curriculum

Figure 3 displays the achievement result of the component content curriculum. The result above explains that component content of curriculum has an average of 4,16, achievement $83 \%$, and discrepancy $13 \%$, so that curriculum content has a very high category.

\subsection{Analysis Component of Learning Activity}

Analysis of learning activity is a standard analysis process on the curriculum. Analysis result of learning activity in a curriculum get an average of 4,07, and the calculation is in the 3,67-5,00 interval. The result can be seen in Table 5 . 
Table 5. Learning Activity Component

\begin{tabular}{ccccc}
\hline Component & $\begin{array}{c}\text { Total } \\
\text { score }\end{array}$ & Average & Percentage & Category \\
\hline $\begin{array}{c}\text { Learning } \\
\text { Activity }\end{array}$ & 5174 & 4,07 & $81 \%$ & $\begin{array}{c}\text { Very } \\
\text { High }\end{array}$ \\
\hline
\end{tabular}

Based on the analysis Table 5 , the average learning activity component is 4,07 , so that the element of the learning activity category is very high. The result can be seen in Figure 4 .

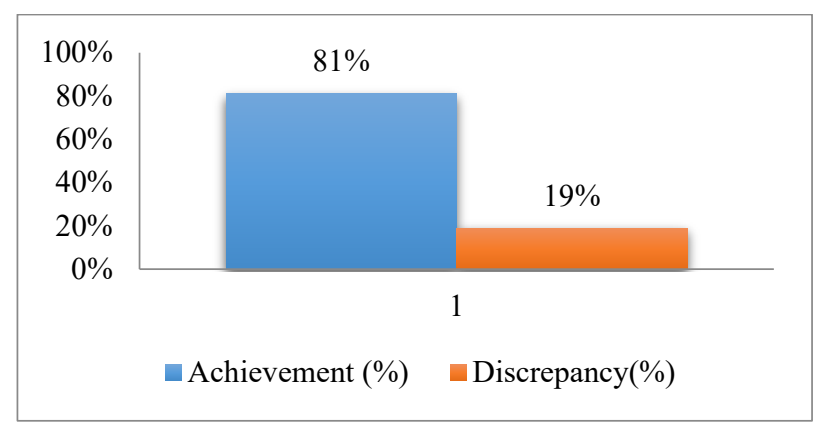

Figure 4. Component of Learning Activity

The analysis of Figure 4 on the learning activity component shows that learning activity has an average of 4,07 , achievement $81 \%$, and discrepancy $19 \%$, so that learning activity component has a very high category.

\subsection{Analysis Component of Learning Result Evaluation}

Curriculum evaluation analysis is a formal analysis of curriculum assessment. Based on the analysis done, the evaluation curriculum's average component is 4,38 , and the calculation is in 3,67-5,00 intervals. The result can be seen in Table 6 .

Table 6. Evaluation Component

\begin{tabular}{ccccc}
\hline Component & $\begin{array}{l}\text { Total } \\
\text { score }\end{array}$ & Average & Percentage & Category \\
\hline Evaluation & 3898 & 4,38 & $88 \%$ & $\begin{array}{l}\text { Very } \\
\text { High }\end{array}$ \\
\hline
\end{tabular}


Based on the analysis result in Table 6 , the category is very high. The average evaluation component is 4,38. Based on the development, the category of evaluation component of learning result is very high. It can be seen in Figure 5.

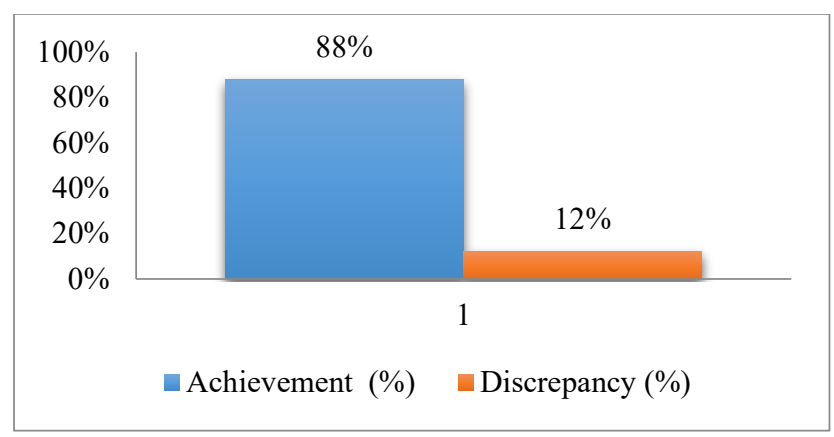

Figure 5. Evaluation Component

Based on Picture 5, the average component evaluation is 4,38 with the achievement of $88 \%$ and a discrepancy of $12 \%$, so that evaluation component has a very high category.

\section{Results and Discussion}

\subsection{Analysis Component of Discrepancy Curriculum}

Analysis component discrepancy is an analysis of the decreased level of curriculum implementation. This analysis is done to know how high fell level in every curriculum component. Curriculum discrepancy can be seen clearly in Table 7.

Table 7. Component of Curriculum Discrepancy

\begin{tabular}{|c|c|c|c|c|c|}
\hline No & Component & Total Score & Average & Percentage & Discrepancy \\
\hline 1 & Objective & 4165 & 4,09 & $82 \%$ & $18 \%$ \\
\hline 2 & Content & 4231 & 4,16 & $83 \%$ & $17 \%$ \\
\hline 3 & $\begin{array}{l}\text { Learning } \\
\text { Activity }\end{array}$ & 5174 & 4,07 & $81 \%$ & $19 \%$ \\
\hline \multirow[t]{2}{*}{4} & Evaluation & 3898 & 3,38 & $88 \%$ & $12 \%$ \\
\hline & Average & 4367 & 3,925 & $84 \%$ & $17 \%$ \\
\hline
\end{tabular}

Based on Table 7, the most significant discrepancy is in the component of learning activity, which is $19 \%$, while the minor difference is in the evaluation component, which is $12 \%$. Table 7 displays curriculum components that consist of objectives, content, learning activity, and evaluation (Bonee, 2014; Nordin, 2013). Based on the discrepancy in all curriculum components, the curriculum is a result curriculum that has not been done yet. Analysis of curriculum discrepancy can be seen in Figure 6. 


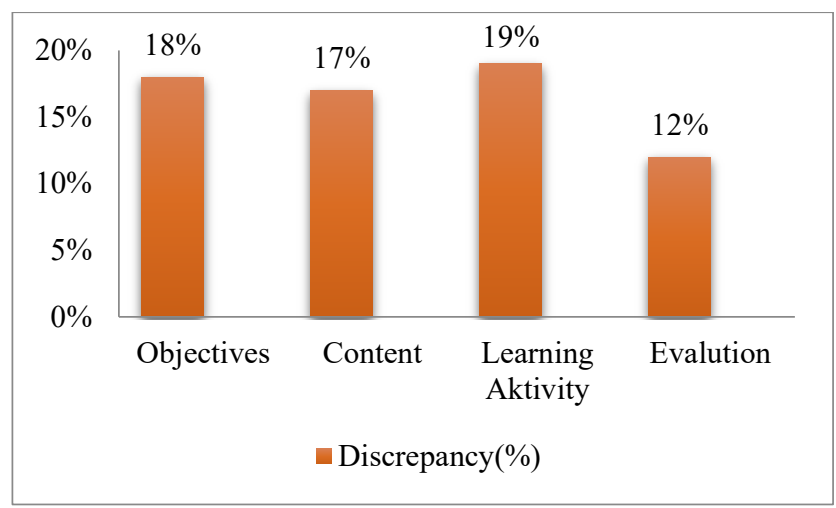

Figure 6. The discrepancy of Curriculum Component

Based on the analysis in Figure 6, every curriculum component has various discrepancies. Objectives components have an average of 4,09 with a distinction of $18 \%$. The content component has an average of 4,16 with a contrast of $17 \%$. Element of learning activity has an average of 4,07 with a discrepancy of $19 \%$. The evaluation component has an average of 3,38, with a distinction of $12 \%$. This result gives information that he highest difference of component curriculum is in learning activity which is $19 \%$. Second, it is an objective component of $18 \%$, and third is the content component which is $17 \%$. Fourth, it is the evaluation component which is $12 \%$. How big the discrepancy is can be seen in Figure 7 .

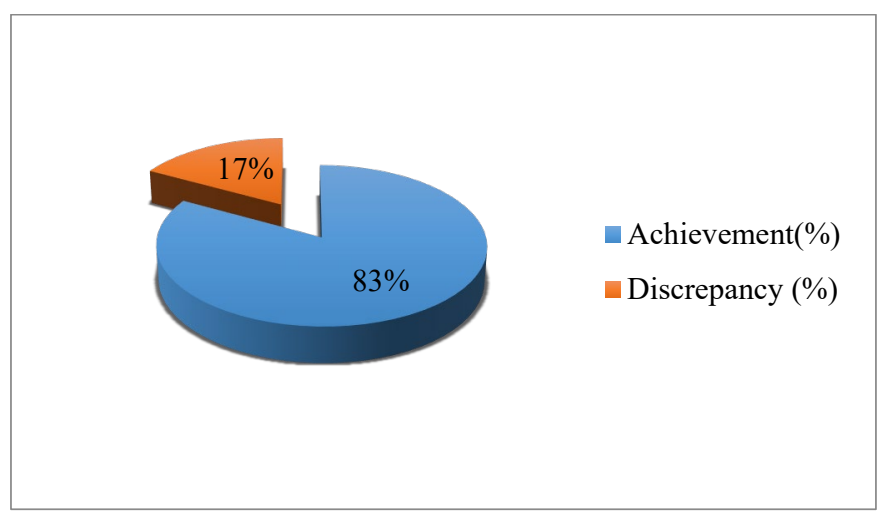

Figure 7. Curriculum Discrepancy

Based on Figure 7, the discrepancy that has not been done yet in Stella Duce Dua Yogyakarta senior high school is $17 \%$. In other words, a curriculum that has not been applied is $17 \%$.

\subsection{Objective Component}

Implementing the curriculum component to the aspects of goals in Stella Duce Dua Yogyakarta's high school is $82 \%$ appropriate. It means that graduate competency standards in national education standard number 20 of 2016 have been applied in the school. A value of $82 \%$ is obtained from students who experience how a teacher uses graduate competency 
standards directly. Most of the students said that teachers and schools in implementing the curriculum were right as the analysis results. Most students consider that schools and teachers are guided by graduate competency standards in implementing the curriculum.

\subsection{Content Components}

Implementing the curriculum component to the aspects of goals in Stella Duce Dua Yogyakarta's high school is $83 \%$ appropriate. It means that the content standards in the national education standard number 21 of 2016 have been applied in schools. This 83\% suitability is obtained from the opinion of most of the students of class XI. It can be concluded that schools in implementing curriculum content are appropriate with the curriculum content standards, as evidenced by the analysis results.

\subsection{Learning Activity Components}

Implementing the curriculum component to the target aspects of Stella Duce Dua Yogyakarta's high school is $81 \%$ appropriate. The standard process contained in the national education standard number 22 of 2016 has been applied in schools. Opinions of most students from schools in the implementation of learning activities are appropriate with the standard process. It can be concluded that the analysis result, which achieves $81 \%$, has been approved.

\subsection{Learning Evaluation Component}

Implementing the curriculum component to the target aspects in Stella Duce Dua Yogyakarta's high school is $88 \%$ appropriate. It means that evaluation of the curriculum in the national education standard number 23 of 2016 has been applied in schools. Most students' opinions in that school in implementing learning activities are appropriate with the standards of the process. The result of the analysis, which achieves $88 \%$, means that it is already fit.

\section{Conclusion}

Based on the result of the research and discussion that has been explained, it can be concluded that: $82 \%$ learning objective which implemented by the teacher in Stella Duce Dua Yogyakarta's high school is very effective. The standard of graduate competency guides the implementation of the curriculum. 83\% of learning content implemented by teachers in Stella Duce Dua Yogyakarta's high school is also very effective. $81 \%$ of the learning activity implemented by the teacher in Stella Duce Dua Yogyakarta's high school is very effective. The standard of graduate competency guides the implementation of the curriculum. $88 \%$ of evaluation of learning results implemented by teachers in Stella Duce Dua Yogyakarta's high school is very effective. The standard guides the implementation of the curriculum involves various aspects. Discrepancy of implementation curriculum is $17 \%$, it is: (1) objectives discrepancy $18 \%$, (2) Content Discrepancy is $17 \%$, (3) Discrepancy of learning activity is $19 \%$, (4) Evaluation discrepancy is $12 \%$.

\section{References}

[1] Li, L., Huang, F., Chen, S., Pan, L., Zeng, W., \& Wu, X. (2020). Exploring the curriculum development in content and language integrated learning: A systematic review. International Journal of Evaluation and Research in Education, 9 (4), 11021113. 
[2] Ruiz de Zarobe and J. Cenoz, (2015). Way forward in the twenty-first century in contentbased instruction: Moving towards integration. Language, Culture and Curriculum, 28 (3), 90-96.

[3] Prasetyono, H., Abdillah, A., Djuhartono, T., Ramdayana, I.P., \& Desnaranti, L. (2021). Improvement of Teacher's Professional Competency in Strengthening Learning Methods to Maximize Curriculum Implementation, International Journal of Evaluation and Research in Education, 10 (2).

[4] Zevin, B. G. Sheahan, S. Ashamalla, N. J. Dedy, D. Jalink, and T. Grantcharov, (2019). Implementation and Evaluation of a Comprehensive Proficiency-Based Curriculum in an Advanced, Minimally Invasive Procedure: A Multi-Institutional Canadian Experience. Surg. Obes. Relat. Dis, 15 (11), 1956-1964

[5] Nasution. (2006). Asas-Asas Kurikulum. Jakarta: Bumi Aksara.

[6] Andrian, D., Kartowagiran, B., \& Hadi, S. (2018). The instrument development to evaluate local curriculum in Indonesia. International Journal of Instruction, 11 (4), $922-$ 934.

[7] Aman. (2019). Final Examination Test Instruments for History Subject in Yogyakarta, Indonesia: A Quality Analysis. Universal Journal of Educational Research, 7 (12), $2857-$ 2866.

[8] Natsir, Y. Qismullah Yusuf, and U. Fiolina Nasution. (2018). The Rise and Fall of Curriculum 2013: Insights on the Attitude Assessment from Practicing Teachers. SHS Web Conf., 42 (2), 1-10.

[9] Ali, M. (2014). Metodologi dan Amplikasi Riset. Jakarta: Bumi Aksara

[10] Arifin, Z. (2011). Evaluasi Pembelajaran. Bandung: Remaja Rosdarakaya

[11] Fitzpatrick, Sanders \& Worthen. (2011). Program evaluation, alternative approach, and practical guideline. Boston: Pearson

[12] Bannet, J. (2006). Evaluation methods in research. New York: Comtinum

[13] Maba, W. and I. B. N. Mantra. (2018). The Primary School Teachers' Competence in Implementing The 2013 Curriculum. SHS Web Conf, 42 (35), 1-7

[14] Setiawan, J., Aman., \& Wulandari. (2020). Understanding Indonesian history. Interest in learning history and national insight with nationalism attitude. International Journal of Evaluation and Research in Education, 9 (1), 1-10.

[15] Provus. M.M. (2009). The discrepancy evaluation model an approach to local program improvement \& development. Pennsylvania: Pittsburgh, public school

[16] Howell, K. W., \& Nollet, V. (2000). Curriculum-based evaluation: Teaching and decision making. Scarborough. Ontario: Wadsworth Thompson Learning.

[17] Umami. (2018). Moderating Influence of Curriculum, Pedagogy, and Assessment Practices on Learning Outcomes in Indonesian Secondary Education. J. Soc. Stud. Educ. Res. 9 (1), 60-75.

[18] Gilakjani, A. P., \& Sabouri, N. B. (2016). How can Students Improve Their Reading Comprehension Skill?. Journal of Studies in Education, 6 (2), 229-240

[19] Werang, B.R. (2018). The Effect of Workload, Individual Characteristics, and School Climate on Teachers' Emotional Exhaustion in Elementary Schools of Papua. Cakrawala Pendidikan, 37 (3), 457-469

[20] Gunduz, A. Y., Alemdag, E., Yasar, S., \& Erdem, M., (2016). Design of a problem-based online learning environment and evaluation of its effectiveness. The Turkish Online Journal of Educational Technology, 15 (3), 49-57

[21] Wright CR, Judith T \& Johnson (Eds.). (2000). Module 13 curriculum theory, design, and assessment. Canada: The Commonwealth Learn. 
[22] Hamalik, O. (2013). Dasar-Dasar Pengembangan Kurikulum. Bandung: Remaja Rosdakarya

[23] Aman. (2019). History Teachers' Competence in Implementing Authentic Assessment: A Case Study in a State Senior High School in Yogyakarta. International Journal of Learning, Teaching and Educational Research, 18 (10), 68-88

[24] Lin, S.H.P \& Jia, Y.K. (2018). Relationships Between LINUS Teachers' Knowledge of Basic Language Constructs, Teaching Experience and Perceived Teaching Abilities. Universal Journal of Educational Research, 6 (9), 1962-1973

[25] Sugiyono. (2016). Metode Penelitian Pendidikan: Pendekatan Kuantitati, Kualitatif dan Campuran. Bandung: Alfabeta

[26] Arikunto, S. (2017). Prosedur Penelitian. Jakarta: Rineka Cipta

[27] Brandy, L. \& Kennedy. K. (2010). Curriculum Construction. Australia: Pearson Education Australia.

[28] Madaus F. George, dkk, (2000). Evaluation Models: Viewpoints on Educational and Human Service Evaluation. Norwell: Kluwer Academic Publisher.

[29] Cavallo, A. M. L., Potter, W. H., \& Rozman, M., (2004). Gender differences in learning constructs, shifts in learning constructs, and relationship to course achievement in a structured inquiry, yearlong college physics course for life science majors. School Science and Mathematics, 104 (6), 288-300

[30] Polit, D. F., \& Beck, C. T. (2006). The content validity index: are you sure you know what's being reported? Critique and recommendations," research in nursing \& health, 29 (5), 489-49 